\title{
The Vocation to Parenthood in the Context of a Demographic Crisis in Poland
}

\begin{abstract}
The vocation to parenthood is a constitutive element of married and family life. However, recent decades show that the number of births in Poland is declining steadily. This, in turn, is leading to a decrease in population and population aging in our homeland. The current situation is called a demographic catastrophe, the consequences of which will be felt in the next decades. It is therefore necessary to take concrete steps to change this situation. The aims of this article are to try to describe the present demographic situation in Poland, to recall the main ideas of the teaching of the Catholic Church on the parental tasks of the family and society, and to identify the most important pastoral task, which the Church in Poland faces in this regard.
\end{abstract}

\section{Keywords}

Pro-Family Policy, marriage, family, parenting, motherhood, paternity, demography, aging.

Parenthood is an essential element of married and family life. Together with love, it is the essence of marriage and by its very nature they are one. The Second Vatican Council expressed this truth in its teaching, emphasizing that „Marriage and conjugal love are by their nature ordained toward the begetting and educating of children. Children are really the supreme gift of marriage and contribute very substantially to the welfare of their parents." ${ }^{1}$ Such a conviction

\footnotetext{
1 Gaudium et spes 50.
} 
is also emphasized by social sciences, which call the family a basic social cell, without which it is difficult to imagine any society as its most important functions include parenthood. As noted by F. Adamski, the family ,is the only reproductive group - which means that only the family reproduces not by receiving members from outside, but by giving birth to children. It therefore maintains the biological continuity of society." ${ }^{2}$ Family is, therefore, an indispensable environment for the growth, development and persistence of society.

It might then seem that such evident statements are understandable and implemented both by families and by society, for every family surely wants to live on in the next generations, that will take and pass on the inheritance received from their ancestors. Likewise, every social community (state, nation) seeks development and consolidation secured by new generations. That is why care for preserving continuity and development should be one of the most important duties of the family and the society.

However, recent decades show that this is not the case, especially in Poland. The birth rate has dropped, which leads to population decline and fast population aging in our country. It is therefore necessary to undertake concrete steps to change this situation, which also poses specific challenges and pastoral tasks for the Catholic Church, to which the vast majority of Polish society belongs. It is therefore justified to first outline the current demographic situation in Poland. Then, before attempting to identify the most important pastoral tasks of the church, it will be essential to recall the main ideas of the teaching of the Catholic Church on the parental tasks of the family and society.

\section{The Demographic Situation in Poland}

For some time, demographers have been alarmed by a declining number of children in Poland. They stress that we are experiencing a demographic collapse and many point out that we are in danger of a demographic catastrophe. For indeed, there have been no simple generation substitutions in Poland for over a dozen or so years, as the fertility rate is statistically below 2.3 children per woman at childbearing age. According to sociologists and the data of the Central Statistical Office of Poland (Główny Urząd Statystyczny - GUS), a significant

${ }^{2}$ F. Adamski, Człowiek istota religijna i rodzinna (Man - religious and family being,) Wydawnictwo PETRUS, Kraków 2013, p. 101. 
decline in births has been observed since 1989, when the fertility rate was 2.1 , and the greatest decline occurred after 2000, when the coefficient did not exceed 1.4, and there were years when it dropped to the level of 1.2 children per woman. Since 2011 the coefficient has been 1.3. ${ }^{3}$

The above facts put Poland among the countries with the lowest natural growth not only in Europe but also in the world. And above all, they make us a country in which the number of persons is decreasing systematically and the population average age is getting higher. The demographers emphasize that if the tendency of low fertility continues, in less than 30 years, Poland will face a major crisis because there will be more people in retirement age than young people able to work. Such a state of affairs will pose a huge threat to the economy and the development of the country, and will endanger the stabilization of the pension system. ${ }^{4}$

The situation is probably influenced by many factors, whose influence has increased since the political transformation in Poland. Among the most important reasons is the increase in marriage age, which accounts for postponing the decision of having the first child. Young people first want to graduate, take up a job to earn enough money to set up and maintain a family and so they start a family only after they have „established themselves financially." In addition, the percentage of people who give up the idea of marrying and lead a career-oriented single life is increasing. ${ }^{5}$ The professional activity of young people plays a very important role in their decision to marry and to have a child, and it should be emphasized that today it is much more important than it was twenty years ago.

Another factor is the growing professional activity of women, and the fear of losing a job after childbirth and maternity leave. Women postpone a decision about maternity, and sometimes give it up entirely, fearing that they might lose the possibility of returning to the job or position, which they occupied before

${ }^{3}$ Cf. E. Frątczak, M. Jeleń-Osiecka, Przemiany płodności - intencje rodzicielskie - relacje międzygeneracyjne $w$ Polsce (Fertility changes - parental intentions - intergenerational relations in Poland), in: Rodzina: dobro zagrożone (Family: The Good Endangered), ed. W. Majkowski, Wydawnictwo Księży Sercanów, Kraków 2015, p. 25.

${ }^{4}$ Cf. K. Opozda, Grozi nam demograficzna katastrofa (We are in danger of a demographic catastrophe), http://fakty.interia.pl/autor/krystyna-opozda/news-grozi-nam-demograficzna-katastrofa,nld,2294458 (30.05.2017).

${ }^{5}$ Cf. K. Slany, Alternatywne formy życia małżeńsko-rodzinnego w ponowoczesnym świecie (Alternative forms of marriage and family life in the postmodern world), Wydawnictwo NOMOS, Kraków 2002, pp. 175-178. 
maternity leave. Moreover, many employers do not want to employ young women planning to become mothers, even though, in the light of the Polish law, the employer cannot terminate the employment of an employee who is on maternity leave or when an employee returns to work after such leave. In addition, an employee is entitled to work in the same position she had before maternity leave. And if it is impossible, due to the changes that took place in the workplace while she was on leave, the employer should offer the employee an equivalent job, or some other job matching her qualifications. In addition, the remuneration for work cannot be lower than the pre-leave pay. All these rights are governed and guaranteed by the Labor Code. ${ }^{6}$ However, in practice these regulations are not always followed, which raises concern for women before they decide about their first or next motherhood.

Among the factors, which have had a significant influence on the declining birth rate in Poland is the lack of pro-family and pro-life policy for many years. The groups that had a significant influence on its shape and implementation, and liberal circles treated the family marginally, engaging more in promoting the so-called alternative forms of family life rather than offering actual help for the families that struggled with everyday problems. Growing unemployment, poor housing conditions and the lack of opportunities for state support and assistance for young married couples often led the couples to postpone a decision to take parental responsibility, limit the number of children to one or two, and sometimes abandon the idea of having children. Only a few years ago, when demographers raised alarm that Poland is in danger of a demographic catastrophe, did the way of talking about parenting began to change, and actions

${ }^{6}$ Art.177 $\$ 1$ reads: "An employer cannot terminate a contract of employment during employee's pregnancy and maternity leave, unless there are grounds for terminating the contract without notice by fault of the employee and the trade union organization that represents the employee agreed to it. Art. $183 \$ 2$ states that "after the end of maternity leave, leave on condition of maternity leave, and paternity leave, the employer lets the employee work in his/her previous position, and, if this is not possible, in a position equivalent to the one held before leave or another, corresponding with his/her professional qualifications, with pay he/she would get if he/she did not take leave." Article $136 \$ 4$ recalls that “An employer shall allow an employee, after the end of his/her parental leave, to work in the previous position and, if that is not possible, in a position equivalent to the one held before the commencement of leave or another position corresponding to his/her professional qualifications with pay no lower than the pay for which the employee was entitled on the day he/she started work in the position held before leave", http://kodeks-pracy.org/VIII-uprawnienia-pracownikow-zwiazane-z-rodzicielstwem/ uprawnienia-pracownikow-zwiazane-z-rodzicielstwem (30.05.2017). 
were taken to increase the fertility of Polish families. The most important one is the pro-family policy of the political elites now in power, which includes the „500+” program. It is important to point out that many European countries, which have experienced a decline in fertility, have been taking action to stimulate birth rates and support families with children for years. This has resulted in a growing number of births. ${ }^{7}$ It cannot be forgotten that actions for the family and its parental duties can only bear fruit after many years, provided that they are systematically continued, and not undertaken only once or occasionally.

In the consolidation of anti-family and anti-parental attitudes, the mass media have also played an important role showing a liberal model of married and family life. On the other hand, the family, based on a stable marriage of man and woman, is often shown as an unfashionable and outdated institution, out of tune with the so-called modern world. Similarly, parenthood is often referred to as "luxury", which not everyone can afford. Therefore, the most common model is $2+1$ family, at most $2+2$, and families with three or more children were presented as at least „strange" or pathological. However, it is important to acknowledge that the media is becoming more and more concerned with issues related to parenting, also in the context of Poland's threatened demographic collapse. This is probably related to the new family policy that is being implemented by the current government.

Looking for the causes of the demographic crisis, which is taking place in Poland now, one cannot overlook the socio-cultural changes. Practical materialism is spreading out and contributing to the rise of hedonistic and selfish attitudes. An attitude to possess more and multiply material goods pushes the issue of having children to the margin of family life. To welcome and educate children entails material costs and less time for oneself, makes it difficult to pursue parents' own career, and limits their ability to make their dreams or plans come true. Such attitudes are also greatly encouraged by certain media which promote models of easy lifestyle, void of effort or sacrifice for others, in which everything is at arm's length and which should be used, as much as possible, to satisfy immediate desires without thinking about what will happen later.

${ }^{7}$ Cf. E. Frątczak, M. Jeleń-Osiecka, Przemiany płodności - intencje rodzicielskie (Fertility changes - parental intentions), p. 17; B. Roguska, Sytuacja polskich rodzin - oceny i postulaty (The situation of Polish families - assessments and postulates), www.cbos.com.pl/SPISKOM. POL/2000/KOM053/KOM053.HTM (30.05.2017). 


\section{Parenthood in the Teaching of the Magisterium of the Church}

The Church has always taught that parenting is an essential element of marriage. In the teaching on the purpose of marriage, which was written by St. Augustine, procreation is listed first; the teaching was confirmed throughout history by the General Councils and the documents of the Magisterium of the Church (e.g., the Council of Trent, Leo XIII in the Encyclical Arcanum divinae sapientiae, Pius XI in the Encyclical Casti connubii.) The Second Vatican Council also addressed the issue of parenthood in the teaching which emphasizes that ,the institution of matrimony itself and conjugal love are ordained for the procreation and education of children," and that "children are really the supreme gift of marriage."

In his teaching, Pope Paul VI devoted a lot of attention to the subject of parenthood, especially in the encyclical Humanae vitae. The Pope showed that a human being created as a man and a woman in God's image and likeness is called to and is capable of love, which in a special way is embodied in spousal conjugal love. Starting from this anthropological foundation, Pope Paul VI emphasized that conjugal love is fecund and "is not confined wholly to the loving interchange of husband and wife; it also contrives to go beyond this to bring new life."' In this context, the pope continued to speak of responsible parenthood, which is the responsibility of the spouses. Love, understood in this way, in which the spouses become a reciprocal gift for each other "requires of husband and wife the full awareness of their obligations in the matter of responsible parenthood," and „requires that husband and wife, keeping a right order of priorities, recognize their own duties toward God, themselves, their families and human society." ${ }^{10}$ Thus, according to Pope Paul VI, not only marriage as an institution, but spouses and their spousal love are the source of parenting. It is also the foundation for the institution of marriage. Both realities are necessary and complement each other in order to enable and assist the spouses in taking up and executing their parental vocation.

Speaking of parenthood, Paul VI reminded us that it is a responsibility to the society in which the family lives. The development and prosperity of society

\footnotetext{
${ }^{8}$ Cf. Gaudium st spes 50 and 48.

9 Humanae vitae 9.

${ }^{10}$ Humanae vitae 10.
} 
depends on the growth of the family. Therefore, the pope pointed out that parenthood is a duty not only to oneself and to the family, but also to society. ${ }^{11}$

Parenting was one of the most important issues for the Pope of Families, John Paul II. For him, the spousal union of marriage is a space of reciprocal gift of man and woman, and at the same time understanding the parental direction of their masculinity and femininity. „The whole exterior constitution of woman's body, its particular aspect, the qualities which, with the power of perennial attractiveness, are at the beginning of the knowledge, which Genesis 4: 1-2 speaks of ("Adam knew Eve his wife"), are in close union with motherhood." ${ }^{2}$ Similarly, the external constitution of man's body, and its attractiveness is the object of the knowledge for a woman and is connected with parenthood (motherhood).

John Paul II emphasized that parenthood is above all a vocation. "Man's coming into being," the Pope said in the Letter to Families, "does not conform to the laws of biology alone, but also, and directly, to God's creative will, which is concerned with the genealogy of the sons and daughters of human families. God „willed” man from the very beginning, and God „wills" him in every act of conception and every human birth. God „wills" man as a being similar to himself, as a person." ${ }^{13}$ Thus, the emergence of every human being has its source in God, who wants man for his own sake and wishes to endow him with life in His image and likeness. From this source also comes the value and dignity of every human being from conception to natural death. This emphasis is particularly important today, when the value of a person is often measured whether he or she is attractive and productive or how much he or she can threaten individual (private) interests.

God wants man for himself. However, God's „I want” must be undertaken and realized by the parents. The creator wants a new human being to be born and invites the spouses to realize this desire. Therefore, as John Paul II further emphasizes, „It is thus necessary that the will of the parents should be in harmony with the will of God. They must want the new human creature in the same way as the Creator wants him: „for himself "' ${ }^{14}$ Thus, the spouses are called to join God's will for a new man, to become co-creators of life in the space of creative

11 Cf. Humanae vitae 10.

12 John Paul II, Mężczyzną i niewiastą stworzył ich (Man and Woman He Created Them), Libreria Editrice Vaticana 1986, p. 86.

13 Gratissimam sane 9.

14 Gratissimam sane 9. 
action of God himself. Therefore, the calling to parenthood is the fulfillment of God's plans and participation in His power, more than the realization of personal intentions or a consequence of the laws of nature.

Teaching about parenthood, John Paul II emphasized that this is a sublime task for which both parents are responsible. They are responsible for building and deepening the interpersonal bond in spousal love so that the act of sexual intercourse is an expression of their love, mutual dedication and giving (communio personarum). It is also responsibility for a possible conception of a new life, for, at that moment, they can become parents transferring life to a new person. Speaking of the responsibility of both of them, the Pope draws particular attention to the responsibility of the man, which is unique, because "although he too is involved in the beginning of the generative process, he is left biologically distant from it; it is within the woman that the process develops." ${ }^{15}$ Hence the great responsibility of the man, whose support the woman needs, just when a new human being is conceived under her heart. This emphasizes the responsibility of both. It is precisely due to the irresponsibility of the man that a drama of the woman takes place when, abandoned and having no support, she sometimes takes a dramatic decision with regard to the conceived and developing new life in her womb. Often, a woman who is unable to find a responsible husband and father of children, renounces marriage and parental plans.

John Paul II also reminded us about the social dimension of parenthood, calling children „the springtime of life, and the anticipation of the future history.” The Pope teaches us that "no country on earth, no political system can think of its own future otherwise than through the image of these new generations that will receive from their parents the manifold heritage of values, duties and aspirations of the nation to which they belong and of the whole human family." ${ }^{16}$ In the context of a demographic collapse in Poland, these words gain a unique meaning. When they were said in 1979, they were a warning and a call for vigilance, because the birth rate in Poland was positive; today, in 2017, they could be read as an accusation and admonition calling for appropriate action to prevent the ongoing demographic collapse.

The issue of parenting in the context of social responsibility is also being addressed by Pope Francis. He emphasizes that "children are the joy of family

\footnotetext{
15 Gratissimam sane 12.

16 Familiaris consortio 26.
} 
and society," and therefore there is a need for the special care for every child. The crisis of modern society, especially in Europe, is considered, by the Pope, as selfishness expressed in an escape from parenthood. Therefore he notes that "[...] a society with a greedy generation, that doesn't want to surround itself with children, that considers them above all worrisome, a weight, a risk, is a depressed society. Let's think of many societies that we know here in Europe. They are depressed societies because they do not want children, they do not have children. The level of birth does not arrive at one percent. /.../ The choice to not have children is selfish." ${ }^{17}$ The family is therefore a constitutive cell of every society without which there is no possibility of its development.

\section{Pastoral tasks of the Church in Poland}

The above-mentioned demographic situation in Poland calls for concrete actions not only to slow down the downward trend of natural growth, but to contribute to its growth. This seems all the more necessary because the demographic crisis has been on the rise for more than 20 years and its effects will be felt by the society over the next several decades. Action is needed on many levels: political, economic, educational, and socio-cultural. In the context of our topic, a question arises as to what pastoral activities the Church in Poland should undertake in response

At the end of his Encyclical Humanae vitae, Pope Paul VI appealed to political authorities, scientists, doctors, members of the nursing profession, and spouses themselves to make the life of the family, which is a community of love and life, the center of attention and action in accordance with the law of nature and the law of God. ${ }^{18}$ However, a special appeal of the Pope is addressed to those who are "counselors and spiritual leaders both of individual men and women and of families," and "brothers in the episcopate, with whom We share more closely the care of the spiritual good of the People of God," i.e. priests and bishops „to devote with all zeal to safeguarding the holiness of marriage, in order to guide

17 Franciszek, Potomstwo (Offspring), in: Papież Franciszek, Rodzina uratuje świat (Pope Francis, The Family Will Save the World), Gliwice 2016, p. 48; cf. also ibid. Adhortacja apostolska o miłości w rodzinie Amoris laetitia, (Apostolic Exhortation The Joy of Love Amoris laetitia), Wydawnictwo św. Stanisława BM, Kraków 2016, pp. 165-167.

${ }^{18}$ Cf. Humanae vitae 23-27. 
married life to its full human and Christian perfection." ${ }^{19}$ The task of the priests is to lead spouses on the path to perfect marriage and family life, and to form their conscience based on the law of God and the teaching of the Magisterium of the Church. The formation of conscience is particularly important in the context of undertaking parental tasks by spouses.

The spouses have an undisputed right to give birth to their children in their chosen time and by their own decision on the number of children. It is both their task and their responsibility to God, in whose power they share and are His associates, to themselves as the persons called to parenthood, to the family of which they are members and to the social community in which they live. But as the Second Vatican Council teaches, the spouses ought to "make decisions by common counsel and effort," and to be aware that ,in their manner of acting, spouses should be aware that they cannot proceed arbitrarily, but must always be governed according to a conscience dutifully conformed to the divine law itself." ${ }^{20}$ With a well-formed conscience, the spouses will be able to properly read their vocation to parenthood, and will have the courage to take parental responsibilities. However, it is necessary to assist the spouses patiently in such a way that the priests, drawing from the riches of Revelation, and the teaching of the Magisterium of the Church, may show them the truth of their vocation to parenthood. Caring for the conscience of the spouses and their formation are among the most important tasks that should be undertaken by priests, and directed towards brides and grooms and spouses. As John Paul II reminds us, „The education of the moral conscience, which makes every human being capable of judging and of discerning the proper ways to achieve self-realization according to his or her original truth, thus becomes a pressing requirement that cannot be renounced." ${ }^{21}$ This reminder is all the more current and necessary, as the couples often say that they lack good spiritual guides.

Another task facing priests is the obligation to show the truth about vocation to parenthood, and the value and dignity of life of every human being from conception to natural death. Parenting requires spouses to be open and ready to accept each conceived life. The denial of such an attitude is the avoidance

19 Humanae vitae 28-30.

${ }^{20}$ Gaudium et spes 50; cf. Charter of the Rights of the Family 3; Gratissimam sane 9; Familiaris consortio 28 .

${ }^{21}$ Familiaris consortio 8. 
of conception through the use of contraception, which is opposed to true spousal love, whose essence includes the fullness of the gift which excludes any limitations contrary to human nature. As John Paul II taught, in using contraception, spouses not only reject parenthood, but "manipulate” and degrade human sexuality,-and with it, themselves and their married partner-by altering its value of "total” self-giving. Thus, the innate language that expresses the total reciprocal self-giving of husband and wife is overlaid, through contraception, by an objectively contradictory language, namely, that of not giving oneself totally to the other."22 The truth, understood in this way, should be conveyed and explained to the spouses by the priests. This is all the more necessary nowadays since some liberal circles, and the mass media, promote contraception and the right to abortion as the only proper solution to parenting problems. They also try to influence spouses, and especially young people, which often results in confusion and uncertainty in searching for the right attitudes. The message of the truth about parenthood should be clear and consistent with the law of God. As John Paul II recalled, „The Church is in no way the author or the arbiter of this norm. In obedience to the truth which is Christ, whose image is reflected in the nature and dignity of the human person, the Church interprets the moral norm and proposes it to all people of good will, without concealing its demands of radicalness and perfection." ${ }^{23}$

Pastoral care should include specific forms of support for families that for various reasons fear parental responsibility, especially for families struggling with economic difficulties or suffering from addictions, large families or single mothers.

The Church in Poland is undertaking a number of activities here, including single-mother homes, the SOS fund and widespread assistance for large families or ones that struggle with material difficulties, which exist in every single diocese. Diocesan and parish branches of CARITAS play a very important role. Apart from financial assistance for families in need, they also organize numerous forms of childcare for such families and organize holidays. All these activities confirm commitment of the Church in Poland to help families struggling with various difficulties, which does not exclude the need to seek new ways and forms of support and help.

\footnotetext{
${ }^{22}$ Familiaris consortio 32.

${ }^{23}$ Familiaris consortio 33.
} 


\section{Conclusion}

According to the GUS statistical data for 2016, there were 382,257 live births in Poland while the number of deaths was 388,009 , i.e. 5752 more than the births. This shows that for many years now there has been a negative natural growth. Poland is also experiencing low fertility rates $-1,36$ (to maintain the population of the country, it should be at least $2.1-2.15)^{24}$ Although the $500+$ program, introduced by the current government, is beginning to bring some signs of improvement of this rate, but it is still a long way to restore the demographic balance of the country. „One thing is certain - Poland needs more children than are born now. Even 400,000 births a year does not guarantee a radical change in the demographic structure. Let us recall that in the eighties - with considerably lower financial wealth - between 560,000 and 720,000 children were born a year." ${ }^{25}$ In addition, it cannot be forgotten that in order to rebuild the demographic structure of the country, at least a dozen or so years of a systematic birth rate growth is needed at the level of simple substitutability of generations.

\section{Bibliography}

Adamski F., Człowiek istota religijna i rodzinna (Man - religious and family being,) Wydawnictwo PETRUS, Kraków 2013.

Franciszek, Potomstwo (Offspring), in: Papież Franciszek, Rodzina uratuje świat (Pope Francis, The Family Will Save the World), Gliwice 2016.

Franciszek, Adhortacja apostolska o miłości w rodzinie Amoris laetitia, (Apostolic Exhortation The Joy of Love Amoris laetitia), Wydawnictwo św. Stanisława BM, Kraków 2016.

Frątczak E., Jeleń-Osiecka M., Przemiany płodności - intencje rodzicielskie - relacje międzygeneracyjne w Polsce (Fertility changes - parental intentions - intergenerational relations in Poland), in: Rodzina: dobro zagrożone (Family: The Good Endangered), ed. W. Majkowski, Wydawnictwo Księży Sercanów, Kraków 2015.

GUS Statistics for 2016: przyrost naturalny wciąż ujemny, ale są symptomy poprawy (Natural growth is still negative, but there are symptoms of improvement), http:// www.pch24.pl/statystyki-gus-za-rok-2016-przyrost-naturalny (30.05.2017).

${ }^{24}$ Cf. GUS Statistics for 2016: przyrost naturalny wciąż ujemny, ale są symptomy poprawy (Natural growth is still negative, but there are symptoms of improvement), http://www.pch24. pl/statystyki-gus-za-rok-2016-przyrost-naturalny (30.05.2017).

${ }^{25}$ GUS Statistics for 2016: przyrost naturalny wciąż ujemny, ale są symptomy poprawy. 
John Paul II, Apostolic exhortation on the role of the Christian family in the modern world Familiaris consortio, Libreria Editrice Vaticana 1981.

John Paul II, Mężczyzna i niewiastą stworzył ich (Man and Woman He Created Them), Libreria Editrice Vaticana 1986.

John Paul II, List do rodzin Gratissimam sane (Letter to Families from Pope John Paul II), Vatican 1994.

Karta Praw Rodziny (Charter of the Rights of the Family), Libreria Editrice Vaticana1983.

Opozda K., Grozi nam demograficzna katastrofa (We are in danger of a demographic catastrophe), http://fakty.interia.pl/autor/krystyna-opozda/news-grozi-nam-demograficzna-katastrofa,nld,2294458 (30.05.2017).

Paul VI, Encyclical letter on the regulation of brith Humanaea vitae, Libreria Editrice Vaticana 1968.

Roguska B., Sytuacja polskich rodzin - oceny i postulaty (The situation of Polish families assessments and postulates), www.cbos.com.pl/SPISKOM.POL/2000/KOM053/ KOM053.HTM (30.05.2017).

Second Vatican Council, Pastoral Constitution the Church in the Modern World Gaudium et spes, in: Sobór Watykański II, Konstytucje, Dekrety, Deklaracjem Pallottinum, Poznań 1967.

Slany K., Alternatywne formy życia małżeńsko-rodzinnego w ponowoczesnym świecie (Alternative forms of marriage and family life in the postmodern world), Wydawnictwo NOMOS, Kraków 2002.

http://kodeks-pracy.org/VIII-uprawnienia-pracownikow-zwiazane-z-rodzicielstwem/ uprawnienia-pracownikow-zwiazane-z-rodzicielstwem (30.05.2017). 